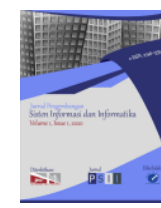

\title{
Peneraapan Model HOT Fit pada Evaluasi Kinerja Human Resources Information System (HRIS) di KPKNL Palembang
}

\author{
Bunga Pertiwi $^{1}$, Evi Yulianingsih ${ }^{2}$ \\ ${ }^{1}$ Informatics Departement, Bina Darma University, Palembang, Indonesia \\ 2,3Information System Departement, Bina Darma University, Palembang, Indonesia \\ Email: ${ }^{1}$ bungapertiwi2910@gmail.com, ${ }^{2}$ ev_yulianingsih@binadarma.ac.id
}

\begin{abstract}
Human Resources Information System (HRIS) is a system that functions to manage all information related to human resources in an institution. This study aims to evaluate and assess the current system and to see the relationship of the variables in the HOT Fit method to HRIS users in KPKNL Palembang. There are three independent variables in this model, each variable has its own sub-variables. Human variables have sub variables: System Users (PS) and User Satisfaction (KP), Organization Variables have sub variables: Organizational Structure (SO) and Organizational Environment (LO), and Technology Variables have sub variables: System Quality (KS), Quality Information (IC), and Service Quality (KL), In addition to the independent variable of this study there are also dependent variables, namely Net Benefit. From these variables, it will be the focus of this research. In this study the authors will use quantitative descriptive research methods by observing, interviewing, and distributing questionnaires. This study uses a Likert scale in measuring employee attitudes and perceptions of the product to be assessed. Because there are only 38 Civil Servants (PNS), all of them will be taken as samples. From this study the authors hope that the agency can use it as a reference in perfecting the current system.
\end{abstract}

Keywords: HRIS, HOT Fit, Evaluation.

\section{PENDAHULUAN}

Perkembangan teknologi informasi saat ini sangatlah pesat dan mengarah pada kecanggihan, dimana hasil perkembangan teknologi informasi tersebut banyak dimanfaatkan dalam aktivitas kehidupan manusia yang bertujuan untuk memberikan kemudahan-kemudahan pada setiap aktivitas. Tanpa terkecuali pada sebuah perusahaan atau instansi yang akan melakukan perbaikanperbaikan untuk membuat perusahaan atau instansi tersebut lebih maju dan 
berkembang. Dengan adanya suatu sistem informasi dapat membantu dalam pengembangan mutu maupun kinerja dari sebuah perusahaan tersebut [1]. Dengan adanya sistem informasi manajemen kepegawaian dapat menghindari kesalahan-kesalahan yang di sebabkan oleh pegawai, staf dan pimpinan. Selain cepat dan mudah dalam menampilkan informasi yang baru oleh adanya update data yang dilakukan pegawai, sistem informasi juga memberikan kemudahan dalam hal penyimpanan data-data pada perusahaan atau instansi, tanpa terkecuali pada Kantor Pelayanan Kekayaan Negara dan Lelang (KPKNL) yang telah menggunakan sistem HRIS untuk pengolahan data kepegawaiannya.

Kantor Pelayanan Kekayaan Negara dan Lelang (KPKNL) Area Palembang, sesuai permenkeu No. 135/PMK.01/2006 tentang organisasi dan tata kerja instansi vertikal Direktorat Jendral Kekayaan Negara (DJKN), tugas-tugas dari KPKNL adalah melaksanakan pelayanan di bidang pengelolaan kekayaan negara, penilaian, piutang negara dan lelang. Pada KPKNL Palembang Sistem yang berjalan saat ini khususnya pada bagian kepegawaiannya dalam penyimpanan dan pengolahan datanya telah menggunakan sistem HRIS.

HRIS adalah suatu sistem pengelolaan SDM didalam suatu instansi untuk memanfatkan kemajuan teknologi informasi. Pada HRIS biasa nya mengolah data-data yang berhubungan dengan karyawan, mengenai cuti, izin, jadwal absen pegawai, serta mengenai gaji. Dengan adanya sistem ini maka memberikan kemudahan-kemudahan bagi pegawai yang mengurus SDM di instansi tersebut dalam melakukan pengolahan data dan membuat laporan rekap penilaian pegawai jika pimpinan memintanya. HRIS dibutuhkan disuatu instansi yang memiliki jumlah pegawai yang banyak untuk mengelola data karyawan dengan efektif dan praktis. HRIS memungkinkan instansi untuk menangani beban kerja lebih banyak dengan sumber daya yang lebih sedikit. Tujuan utama HRIS adalah instansi memiliki data karyawan yang terpercaya untuk mendukung kegiatan operasional dan penyusunan strategi yang lebih baik untuk instansi.

Evaluasi merupakan suatu proses menjelaskan, memperoleh dan menyediakan data yang berguna untuk menilai suatu tindakan atau suatu pelaksanaan sistem yang telah berjalan atau yang sedang berjalan didalam suatu instansi. Dengan evaluasi, capaian kegiatan penyelenggaraan suatu sistem informasi dapat diketahui dan tindakan lebih lanjut dapat direncanakan untuk memperbaiki kinerja penerapannya [2] . Pada penelitian ini penulis menggunakan salah satu metode untuk melakukan evaluasi sistem yaitu model HOT Fit, penulis akan mengkelompok kan 2 variabel yaitu Variabel Independent (bebas) berupa Human, Organization, Technologi dan Variabel Dependent (terikat) berupa manfaat sistem (net benefit). Pada variabel independent yang saling 
berhubungan dimana setiap variabel terdapat sub-sub variabel tersendiri. Variabel Human memiliki sub variabel : Pengguna Sistem (PS) dan Kepuasan Pengguna (KP), Variabel Organization memiliki sub variabel : Struktur Organisasi (SO) dan Lingkungan Organisasi (LO), dan Variabel Technology memiliki sub variabel : Kualitas Sistem (KS), Kualitas Informasi, dan Kualitas Layanan (KL), serta manfaat keseluruhan dari setiap variabel dan sub-sub variabel yang nantinya akan dibuat indikator untuk kuesioner. Karena Pegawai Negeri Sipil (PNS) hanya 38 orang akan diambil jumlah semuanya sebagai sampel. Jadi besar sampel dalam penelitian ini sebanyak 38 responden. Hasil evaluasi ini diharapkan dapat digunakan sebagai acuan untuk menyempurnakan sistem HRIS, atau pun untuk mengembangkan semua kelebihan yang masih ada, sehingga bisa bermanfaat untuk pihak instansi.

Berdasarkan uraian latar belakang di atas maka penulis melakukan penelitian dengan mengambil judul "Penerapan Model HOT Fit pada Evaluasi Kinerja Human Resources Information System (HRIS) di KPKNL Palembang” yang mana nanti pada penelitian ini diharapkan dapat memberikan beberapa manfaat dalam meningkatakan kinerja pada KPKNL Palembang.

\section{METODE}

Dari model-model evaluasi sistem yang ada, Hot Fit model merupakan model yang lengkap dan paling sesuai dengan kondisi permasalahan yang ada dibandingkan dengan model yang lain. Dalam rangka mewujudkan manfaat dari TI, tiga prasyarat yang diperlukan untuk sukses yaitu kerangka evaluasi yang diusulkan, dikembangkan setelah kritis dinilai temuan yang ada pada sistem, dan Information System (IS) studi evaluasi. Pada model ini menyesuaikan manusia dan organisasi berdasarkan kebutuhan mereka. Untuk model HOT FIT dapat di lihat pada gambar dibawah ini [3].

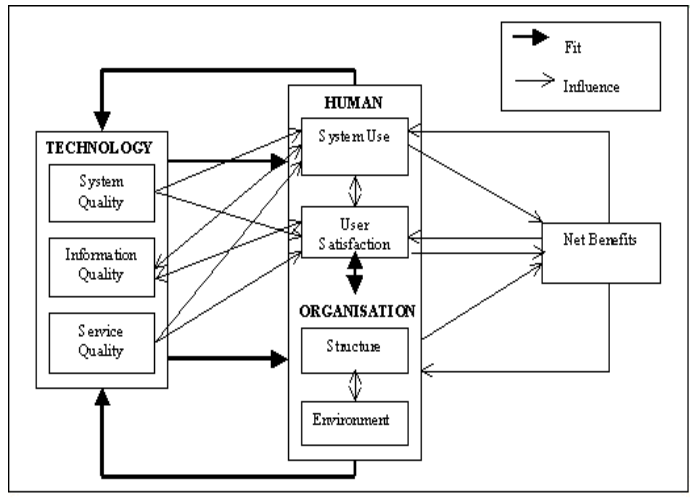

Gambar 1. Model HOT Fit 
Pada penelitian ini penulis akan menggunakan metode penelitian deskriptif kuantitatif dengan melakukan observasi dan wawancara dengan seluruh pegawai yang aktif menggunakan sistem HRIS, Responden pada penelitian ini yaitu apabila jumlah responden kurang dari 100 sampel diambil semua sehingga penelitian ini merupakan penelitian populasi, tetapi jika jumlah responden besar atau lebih dari 100 dapat diambil 10\%-15\% atau 20\%-25\% atau lebih [4]. Pada penelitian ini responden nya merupakan Pegawai Negeri Sipil (PNS) yang berjumlah 38 orang, sehingga jumlah populasi nya sebanyak 38 responden, hal ini berdasarkan teori tersebut yaitu karena jumlah PNS kurang dari 100 sehingga diambil semuanya sebagai sampel. Jadi besar sampel dalam penelitian ini sebanyak 38 responden. Dalam menguji hipotesis dipenelitian ini menggunakan Hipotesis Penelitian dengan bentuk Hipotesis Asosiatif karena penelitian ini merupakan penelitian populasi, maka tidak ada hipotesis statistic [5]. HRIS didefinisikan sebagai sistem yang menyediakan informasi bagi manajer secara menyeluruh tentang sumber daya manusia organisasi [6]. Uji validitas yang telah dilakukan oleh penulis dengan bantuan SPSS versi 20 for window. Kerangka pemikiran yang digunakan dalam penelitian ini yang merujuk pada penelitian sebelumnya yaitu sebagai berikut :

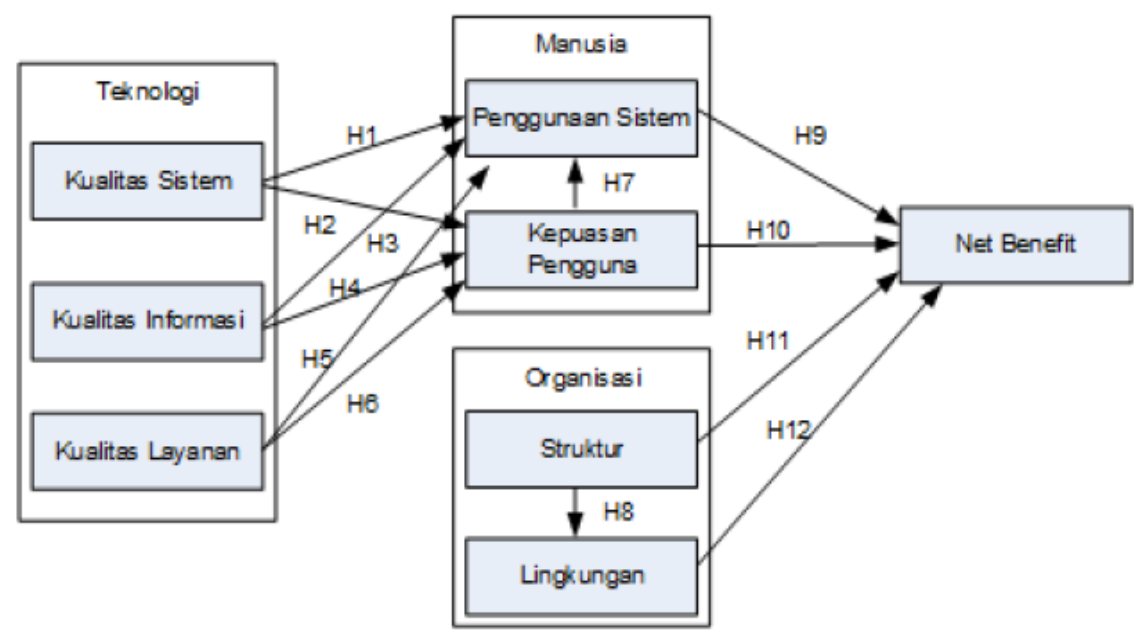

Figure 2. Kerangka Pemikiran [7].

Uji hipotesis dilakukan dengan uji t-statistik, untuk menguji hubungan antar variabel-variabel apakah berpengaruh atau tidak. Dari tabel hasil uji t-statistik dapat diketahui hipotesis ditolak ataupun diterima dengan melihat nilai dari tstatistik dibandingkan dengn $\mathrm{t}$ tabel, dalam penelitian hipotesis ini tingkat signifikansi adalah 95\% $(\alpha=0,05)$ nilai $\mathrm{t}$ tabel dengan tingkat signifikansi 95\% dengan melihat nilai $d f$ adalah sebesar 2,026. 


\section{HASIL DAN PEMBAHASAN}

Pengolahan hasil data kuesioner pada penelitian ini menggunakan SPSS versi 20, tool ini digunakan untuk membantu dalam pengolahan data analisa. Dari hasil yang sudah didapatkan penulis berharap penelitian ini dapat memberikan rekomendasi masukan terhadap sistem yang ada pada KPKNL Palembang.

\subsection{Hasil}

\subsubsection{Uji Validitas}

Keputusan uji validitas yang dilakkukan berdasarkan jika $\mathrm{r}$ hitung pada setiap butir pertanyaan lebih besar dengan nilai $r$ tabel maka hasil dikatakan valid. Berdasarkan hasil $r$ hitung yang telah didapat dengan nilai $r$ tabel dengan $\mathrm{N}=$ 38 dan signifikansi 5\%, yaitu $\mathrm{r}$ tabel $=0,320$ maka kesimpulan dari pengolahan data menyatakan dari semua variabel Human, Organitazion,Technology,dan Net Benefit Valid.

\subsubsection{Uji Realibilitas}

Ada beberapa cara untuk menguji reabilitas internal. Pemilihan metode ini sangat tergantung kepada selera penelitiserta bentuk instrumen [8]. Uji Reliabilitas yang telah dilakukan pada penelitian ini menggunakan teknik Cronbach's Alpha. Analisis pengambilan keputusan Cronbach's Alpha adalah:

Jika rhitung $>$ rtabel, maka reliabel

Jika rhitung < rtabel, maka tidak reliabel

Pada tabel nilai Alpha adalah 0,928 sebagi nilai $r$ hitung, hasil ini akan dibandingkan dengan nilai $r$ tabel $=0,320$. Uji reliabilitas terlihat pada tabel dibawah ini derajat reliabilitas 0,928 berada pada taraf sangat kuat dan jumlah item pertanyaan sebanyak 40.

Tabel 1. Tabel reliabilitas

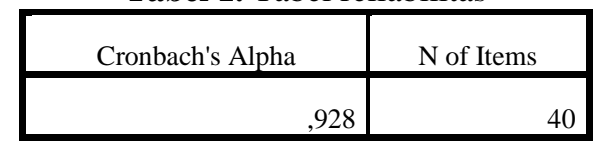

\subsubsection{Uji T Statistik}

Dari tabel dibawah dapat diketahui hipotesis ditolak atau diterima dengan melihat nilai dari $t$ statistik dibandingkan dengan $t$ tabel, serta nilai signifikansi dengan menggunakan batas signifikansi 0,05. 
http://journal.jis-institute.org/index.php/jpsii/index

Tabel 2. Hasil Uji T Statistik

\begin{tabular}{|c|c|c|c|c|c|c|c|c|c|}
\hline & & \multicolumn{4}{|c|}{ Paired Differences } & & \multirow{3}{*}{$t$} & \multirow{3}{*}{$d f$} & \multirow{3}{*}{$\begin{array}{l}\text { Sig. (2- } \\
\text { tailed) }\end{array}$} \\
\hline & & \multirow[t]{2}{*}{ Mean } & $\begin{array}{c}\text { Std. } \\
\text { Deviation }\end{array}$ & $\begin{array}{c}\text { Std. } \\
\text { Error } \\
\text { Mean }\end{array}$ & $\begin{array}{c}95 \% \\
\text { Confidence } \\
\text { Interval of } \\
\text { the } \\
\text { Difference }\end{array}$ & & & & \\
\hline & & & & & Lower & Upper & & & \\
\hline Pair 1 & $\begin{array}{c}\text { SKOR.KS - } \\
\text { SKOR.PS }\end{array}$ & ,921 & 3,183 &, 516 &,- 125 & 1,967 & 1,784 & 37 & ,083 \\
\hline Pair 2 & $\begin{array}{c}\text { SKOR.KS - } \\
\text { SKOR.KP }\end{array}$ &,- 053 & 1,916 &, 311 &,- 683 & ,577 &,- 169 & 37 & ,866 \\
\hline Pair 3 & $\begin{array}{c}\text { SKOR.KI - } \\
\text { SKOR.PS }\end{array}$ & 1,158 & 2,636 &, 428 & ,292 & 2,024 & 2,708 & 37 &, 010 \\
\hline Pair 4 & $\begin{array}{l}\text { SKOR.KI - } \\
\text { SKOR.KP }\end{array}$ &, 184 & 1,658 &, 269 &,- 361 & ,729 &, 685 & 37 & ,498 \\
\hline Pair 5 & $\begin{array}{c}\text { SKOR.KL - } \\
\text { SKOR.PS }\end{array}$ &,- 026 & 3,568 & ,579 & $-1,199$ & 1,146 &,- 045 & 37 & ,964 \\
\hline Pair 6 & $\begin{array}{c}\text { SKOR.KL - } \\
\text { SKOR.KP }\end{array}$ & $-1,000$ & 3,058 & ,496 & $-2,005$ & ,005 & $-2,016$ & 37 &, 051 \\
\hline Pair 7 & $\begin{array}{c}\text { SKOR.KP - } \\
\text { SKOR.PS }\end{array}$ & ,974 & 2,584 &, 419 &, 124 & 1,823 & 2,323 & 37 & ,026 \\
\hline Pair 8 & $\begin{array}{c}\text { SKOR.SO - } \\
\text { SKOR.LO }\end{array}$ & 1,342 & 2,897 &, 470 & ,390 & 2,294 & 2,856 & 37 &, 007 \\
\hline Pair 9 & $\begin{array}{c}\text { SKOR.PS - } \\
\text { SKOR.NB }\end{array}$ &,- 553 & 2,512 & ,407 & $-1,378$ & ,273 & $-1,356$ & 37 &, 183 \\
\hline Pair 10 & $\begin{array}{c}\text { SKOR.KP - } \\
\text { SKOR.NB }\end{array}$ & ,421 & 2,834 &, 460 &,- 511 & 1,353 & ,916 & 37 & ,366 \\
\hline Pair 11 & $\begin{array}{c}\text { SKOR.SO - } \\
\text { SKOR.NB }\end{array}$ &,- 263 & 2,088 &, 339 &,- 950 & ,423 &,- 777 & 37 & ,442 \\
\hline Pair 12 & $\begin{array}{c}\text { SKOR.LO - } \\
\text { SKOR.NB }\end{array}$ & $-1,605$ & 3,445 &, 559 & $-2,738$ &,- 473 & $-2,873$ & 37 & ,007 \\
\hline
\end{tabular}

\subsection{Pembahasan}

Pada penelitian ini penulis menggunakan Uji T berpasangan yang merujuk pada penelitian sebelumnya, berikut ini penjelasan hipotesis dari hasil pengolahan data melalui spss. 


\subsubsection{Uji Hipotesis}

Pengujian hasil hipotesis dengan melihat besarnya nilai t statistik dan sig pada tabel 3 dalam penelitian ini tingkat signifikansi adalah $95 \%(\alpha=0,05)$ nilai $\mathrm{t}$ tabel dengan tingkat signifikansi $95 \%$ dengan melihat nilai $d f$ adalah sebesar 2,026. Dimana suatu hipotesis akan diterima bila memiliki t statistik lebih besar dari 2,026 dan bila memiliki t statistik lebih kecil dari 2,026 maka suatu hipotesis akan ditolak, maka dapat diketahui uji hipotesis dalam penelitian ini sebagai berikut:

H1 : Kualitas sistem (System Quality) mempengaruhi terhadap pengguna sistem (System Use). Tingkat signifikansi 0,083 dengan menggunakan batas signifikansi 0,05 , nilai signifikansi tersebut lebih kecil dari taraf 5\% yang berarti $H_{0}$ ditolak dan $H_{1}$ diterima. Artinya kualitas sistem mempunyai pengaruh terhadap pengguna sistem.

H2 : Kualitas sistem (System Quality) mempengaruhi terhadap kepuasaan pengguna (User satisfaction) . Tingkat signifikansi 0,866 dengan menggunakan batas signifikansi 0,05 , nilai signifikansi tersebut lebih besar dari taraf $5 \%$ yang berarti $H_{0}$ diterima dan $H_{1}$ ditolak. Artinya kualitas sistem tidak mempunyai pengaruh terhadap kepuasaan pengguna.

H3 : Kualitas informasi (Information Quality) tidak mempengaruhi terhadap pengguna sistem (System Use) Tingkat signifikansi 0,010 dengan menggunakan batas signifikansi 0,05 , nilai signifikansi tersebut lebih kecil dari taraf 5\% yang berarti $H_{0}$ ditolak dan $H_{1}$ diterima. Artinya kualitas informasi mempunyai pengaruh terhadap pengguna sistem.

H4 : Kualitas informasi (Information Quality) mempengaruhi terhadap kepuasaan pengguna (User satisfaction) Tingkat signifikansi 0,498 dengan menggunakan batas signifikansi 0,05 , nilai signifikansi tersebut lebih besar dari taraf $5 \%$ yang berarti $H_{0}$ diterima dan $H_{1}$ ditolak. Artinya kualitas informasi tidak mempunyai pengaruh terhadap kepuasaan pengguna.

H5 : Kualitas layanan (Service Quality) mempengaruhi terhadap pengguna sistem (System use) Tingkat signifikansi 0,964 dengan menggunakan batas signifikansi 0,05 , nilai signifikansi tersebut lebih besar dari taraf $5 \%$ yang berarti $H_{0}$ diterima dan $H_{1}$ ditolak. Artinya kualitas layanan tidak mempunyai pengaruh terhadap pengguna sistem.

H6 : Kualitas layanan (Service Quality) mempengaruhi terhadap kepuasaan pengguna (User satisfaction) Tingkat signifikansi 0,051 dengan menggunakan batas signifikansi 0,05 , nilai signifikansi tersebut lebih kecil dari taraf 5\% yang berarti $H_{0}$ ditolak dan $H_{1}$ diterima. Artinya kualitas layanan mempunyai pengaruh terhadap kepuasaan pengguna. 
H7 : Kepuasaan pengguna (User Satisfaction)Tingkat signifikansi 0,026 dengan menggunakan batas signifikansi 0,05 , nilai signifikansi tersebut lebih kecil dari taraf $5 \%$ yang berarti $H_{0}$ ditolak dan $H_{1}$ diterima. Artinya kepuasaan pengguna mempunyai pengaruh terhadap pengguna sistem.

H8 : Struktur organisasi (Structure) Tingkat signifikansi 0,007 dengan menggunakan batas signifikansi 0,05 , nilai signifikansi tersebut lebih kecil dari taraf 5\% yang berarti $H_{0}$ ditolak dan $H_{1}$ diterima. Artinya struktur organisasi mempunyai pengaruh terhadap lingkungan organisasi.

H9 : Pengguna sistem (system use) mempengaruhi terhadap net benefit Tingkat signifikansi 0,183 dengan menggunakan batas signifikansi 0,05 , nilai signifikansi tersebut lebih besar dari taraf $5 \%$ yang berarti $H_{0}$ diterima dan $H_{1}$ ditolak. Artinya pengguna sistem tidak mempunyai pengaruh terhadap net benefit.

H10: Kepuasan pengguna (user satisfaction) Tingkat signifikansi 0,366 dengan menggunakan batas signifikansi 0,05 , nilai signifikansi tersebut lebih besar dari taraf $5 \%$ yang berarti $H_{0}$ diterima dan $H_{1}$ ditolak. Artinya kepuasaan pengguna tidak mempunyai pengaruh terhadap net benefit.

H11: Struktur organisasi (Structure) Tingkat signifikansi 0,442 dengan menggunakan batas signifikansi 0,05 , nilai signifikansi tersebut lebih besar dari taraf $5 \%$ yang berarti $H_{0}$ diterima dan $H_{1}$ ditolak. Artinya sstruktur organisasi tidak mempunyai pengaruh terhadap net benefit

H12: Lingkungan organisasi (Environment)Tingkat signifikansi 0,007 dengan menggunakan batas signifikansi 0,05 , nilai signifikansi tersebut lebih kecil dari taraf $5 \%$ yang berarti $H_{0}$ ditolak dan $H_{1}$ diterima. Artinya lingkungan organisasi mempunyai pengaruh terhadap net benefit.

\section{KESIMPULAN}

Keberhasilan dalam penerapan HRIS KPKNL Palembang dipengaruhi oleh faktor kualitas informasi dengan nilai 2,708, kepuasaan pengguna dengan nilai 2,323 , struktur organisasi dengan nilai 2,856, lingkungan organisasi dengan nilai 2,873, dan net benefit. Lingkungan organisasi merupakan faktor yang memberikan pengaruh paling besar. HRIS dapat ditingkatkan dengan kualitas sistem agar kepuasaan pengguna dapat meningkat dan berdampak bagi human dan organisation dan Untuk mendukung suatu sistem informasi dapat lebih ditingkatkan lagi melalui strategi dan manajemen seperti dukungan pemimpin, kerja antar tim, dan komunikasi. 


\section{DAFTAR PUSTAKA}

[1] Subchan and A. Bagus Kusuma, "Peranan Strategi Sistem Informasi Manajemen Untuk Mencapai Tujuan," J. Ekon. Manaj. dan Akunt., pp. 1-14, 2014.

[2] R. Murnita and E. Sediyono, "Evaluasi Kinerja Sistem Informasi Manajemen Farmasi di RS. Roemani Muhammadiyah dengan Metode HOT Fit Model," Manaj. Kesehat. Indones., vol. 4, 2016.

[3] Y. Maryati Mohd., P. Ray J., and S. Lampros K., "Towards a Framework for Health Information Systems Evaluation," Proc. 39th Hawaii Int. Conf. Syst. Sci., pp. 1-10, 2006.

[4] I. AGUSTINA, "Analisis Pengaruh Gaji Dan Tunjangan Kesejahteraan Terhadap Produktivitas Kerja Karyawan Operation Department PT. Export Leaf Indonesia.," J. Paradig., vol. 12, pp. 41-56, 2014.

[5] Sugiyono, Metode Penelitian Pendidikan, Pendekatan Kuantitatif, Kualitatif, dan R\&D. Bandung: Alfabeta, 2013.

[6] M. R and Schell, Sistem Informasi Manajemen Title. jakarta: PT. Index, 2007.

[7] K. Dwi, S. M, and L. E.T, "Evaluasi Keberhasilan Implementasi Sistem Informasi Dengan Pendekatan Hot Fit Model (Studi Kasus: Perpustakaan STMIK AMIKOM Purwokerto)," Konf. Nas. Sist. Inform., pp. 896-901, 2015.

[8] Suliyanto, Metode Penelitian Bisnis untuk Skripsi, Tesis, \& Disertasi. Yogyakarta, 2018. 